\title{
The Klebsiella pneumoniae cytochrome bd' terminal oxidase complex and its role in microaerobic nitrogen fixation
}

\author{
Navtej S. Juty, ${ }^{1,2}+$ Farhad Moshiri, ${ }^{3} \ddagger$ Mike Merrick, ${ }^{2}$ Christopher Anthony ${ }^{1}$ \\ and Susan Hill ${ }^{2}$
}

\footnotetext{
1 Department of Biochemistry, University of Southampton,

Southampton SO16 7PX, UK

2 Nitrogen Fixation Laboratory, John Innes Centre, Norwich NR4 7UH, UK

3 Department of Biology, The Johns Hopkins University, Baltimore, MD 21218, USA
}

Author for correspondence: Susan Hill. Tel: +441603456900 ext. 2749. Fax: +441603454970.

\begin{abstract}
Cytochrome bd' has been implicated in having an important role in microaerobic nitrogen fixation in the enteric bacterium Klebsiella pneumoniae, where it is expressed under all conditions that permit diazotrophy. In this paper the sequence of the genes encoding this terminal oxidase (cydAB) of Klebsiella pneumoniae and the characterization of a cyd mutant are reported. The deduced amino acid sequences support the proposal that His 19, His 186 and Met 393 provide three of the four axial ligands to the Fe of the three haems in the oxidase complex. The nitrogen-fixing ability of the mutant was severely impaired in the presence of low concentrations of oxygen compared with the wild-type bacterium. Only the wild-type organism was capable of microaerobic nitrogenase activity supported by fermentation products. It is proposed that formate dehydrogenase- 0 may be involved in supplying electrons to a respiratory chain terminated by the bd-type oxidase, which would remove inhibitory oxygen and supply ATP for nitrogenase activity.
\end{abstract}

Keywords: Klebsiella pneumoniae, cydAB, cytochrome $b d^{\prime}$, nitrogen fixation, formate dehydrogenase-O

\section{INTRODUCTION}

The enzymes responsible for $\mathrm{N}_{2}$ fixation, the nitrogenases, are very sensitive to $\mathrm{O}_{2}$. To reduce $\mathrm{N}_{2}$ to $2 \mathrm{NH}_{3}$ they require a source of low-potential reductant (between -400 and $-500 \mathrm{mV}$ at $\mathrm{pH} 7$ ) as well as a minimum of 16 moles of ATP per mole of $\mathrm{N}_{2}$ fixed (see Hill, 1992). The ability to fix $\mathrm{N}_{2}$ is widely distributed amongst obligate anaerobic, facultative anaerobic and obligate aerobic prokaryotes (Young, 1992), where the most commonly occurring nitrogenases are Mo-dependent enzymes (Bishop \& Premakumar, 1992). Clearly, the capacity to carry out an aerobic catabolism should help satisfy the high ATP requirement, but it could be detrimental as a result of inactivation of nitrogenase by $\mathrm{O}_{2}$. A range of strategies in different bacteria have been adopted to cope with this apparent paradox (Sprent \& Sprent, 1990). For example, the obligately aerobic

†Present address: City of Hope National Medical Center, Division of Pediatrics, 1500 East Duarte Road, Duarte, CA 91010-0269, USA.

‡Present address: Mail Zone GG4G, Ceregen, A Unit of Monsanto, 700 Chesterfield Parkway, St Louis, MO 63198, USA.

The EMBL accession number for the sequence reported in this paper is Y10012.
Azotobacter vinelandii can fix $\mathrm{N}_{2}$ in air-saturated media $\left(225 \mu \mathrm{M} \mathrm{O}_{2}\right.$ ) (Poste et al., 1983). It has an extremely active cytochrome $b d$-type terminal oxidase, which plays an important part in removing unwanted $\mathrm{O}_{2}$, as has been shown by a mutant lacking this oxidase becoming an obligate microaerophile when fixing $\mathrm{N}_{2}$ (Kelly et al., 1990). By contrast, the facultative anaerobe Klebsiella pneumoniae fixes $\mathrm{N}_{2}$ anaerobically using a fermentative catabolism (Hill, 1976b), with no $\mathrm{N}_{2}$ fixation occurring in aerobic conditions. However, microaerobic respiration can benefit diazotrophy; the efficiency of $\mathrm{N}_{2}$ fixation (moles $\mathrm{N}_{2}$ fixed per mole glucose consumed) in glucose-limited chemostats is increased by providing low levels of $\mathrm{O}_{2}$ ( Hill, 1976a, b). Nitrogenase activity in such populations is dependent upon $\mathrm{O}_{2}$ (Hill, 1976a) and is maximal at a dissolved $\mathrm{O}_{2}$ concentration of $30 \mathrm{nM}$ (Kavanagh \& Hill, 1990). Thus, microaerobic catabolic activity supported by fermentation products appears to provide both ATP and electrons for nitrogenase activity in K. pneumoniae. The source of electrons for nitrogenase activity in $K$. pneumoniae is the nif-specific pyruvate:flavodoxin oxidoreductase (Hill \& Kavanagh, 1980; Shah et al., 1983) an enzyme that is very $\mathrm{O}_{2}$ sensitive (Shah et al., 1983). Thus the function of microaerobic respiratory 
activity under these conditions is probably to prevent $\mathrm{O}_{2}$ from inhibiting nitrogenase and the pyruvate: flavodoxin oxidoreductase as well as to provide ATP.

K. pneumoniae, like Escherichia coli, has a branched respiratory chain terminating in two oxidases of the cytochrome bo- and $b d$-types (Smith et al., 1990; Anraku $\&$ Gennis, 1987). Whether K. pneumoniae carries the $a p p$ locus, which in $E$. coli encodes a second $b d$-type oxidase (Dassa et al., 1991; Sturr et al., 1996), is unknown. In both organisms the low-affinity cytochrome $b o^{\prime}$ is the principal oxidase under aerobic conditions, whereas under microaerobic or anaerobic conditions the high-affinity cytochrome $b d^{\prime}$ predominates (Smith et al., 1990; Tseng et al., 1996); the latter conditions are those that permit diazotrophy in $K$. pneumoniae (Smith et al., 1990). In A. vinelandii, by contrast, conditions of high $\mathrm{O}_{2}$ input lead to enhanced synthesis of the cytochrome $b d^{\prime}$ (D'mello et al., 1997, and references therein). The cytochrome $b d^{\prime}$ from $E$. coli (Kita et al., 1984), K. pneumoniae (Smith et al., 1990) and A. vinelandii (Kolonay et al., 1994; Jünemann et al., 1995) have been purified. They are membrane-bound dimeric ubiquinol oxidases containing haems B and D. In general their properties are similar, except that the values for $k_{\text {cat }}$ and the apparent $K_{\mathrm{m}}$ values for $\mathrm{O}_{2}$ differ, being lower for the $E$. coli and $K$. pneumoniae enzymes than for the $A$. vinelandii enzyme. The apparent $K_{\mathrm{m}}$ values for $E$. coli (8 nM) (D'mello et al., 1996) and $K$. pneumoniae (20 nM) (Smith et al., 1990) are much lower than that for A. vinelandii $(4 \cdot 5 \mu \mathrm{M})$ (D'mello et al., 1994; Kolonay et al., 1994).

The molecular and genetic characterization of the E. coli cytochrome $b d^{\prime}$ has been extensive. Subunit I (cytochrome $b_{558}$ ) is encoded by $c y d A$, and subunit II (which contains haem $b_{595}$ and haem $d$ ) is encoded by $c y d B$ (Green et al., 1988). The cydAB genes are co-transcribed from a promoter upstream of $c y d A$ and are separated by $18 \mathrm{bp}$ (Fang \& Gennis, 1993). In subunit I the axial ligands of haem $b_{558}$ are His 186 and Met 393 (Fang et al., 1989; Kaysser et al., 1995); this haem serves to transfer electrons from ubiquinol to the oxidase. In addition, His 19 in subunit $I$ is probably an axial ligand for haem $b_{595}$ of subunit II ( Sun et al., 1996). Subunit I also contains a hydrophobic stretch of 11 amino acids, termed the Q-loop, which resides on the periplasmic side of the inner membrane and probably forms part of the binding site for ubiquinol (Dueweke \& Gennis, 1991). The A. vinelandii bd-type oxidase is also encoded by two co-transcribed genes (Moshiri et al., 1991b). The deduced amino acid sequences of these show considerable homology with those of $E$. coli $c y d A B(68 \%$ for subunit I and $83 \%$ for subunit II) (Moshiri et al., 1991a). In the A. vinelandii subunit I His 22 and His 188 probably correspond to the axial ligands His 19 and His 186 in the subunit I of $E$. coli. Although $E$. coli does not fix $\mathrm{N}_{2}$ it can do so when carrying the K. pneumoniae nif gene cluster on a plasmid. Wild-type transconjugants fix $\mathrm{N}_{2}$ under anaerobic conditions (Postgate et al., 1987). Moreover, $\mathrm{O}_{2}$-dependent nitrogenase activity occurs under the similar microaerobic conditions $\left(30 \mathrm{nM} \mathrm{O}_{2}\right)$ as in K. pneumoniae (Hill et al., 1984, 1994). However, an $E$. colicyd mutant harbouring the nif plasmid showed no microaerobic nitrogenase activity although the anaerobic activity was unimpaired (Hill et al., 1990). Thus in the heterologous expression host $E$. coli, cytochrome $b d^{\prime}$ appears to be needed for microaerobic nitrogenase activity. This paper describes the construction of an insertion mutation in cydA of the $K$. pneumoniae chromosome, which resulted in a strain being unable to make the cytochrome $b d^{\prime}$, to assess the roles of this oxidase in microaeroic nitrogenase activity. A preliminary summary of some of this work has been published elsewhere (Juty et al., 1995).

\section{METHODS}

Media and growth conditions. Bacteria were grown at $28^{\circ} \mathrm{C}$ on Luria-Bertiani (LB) medium containing double-concentration yeast extract and Tryptone, nutrient broth (NB) (Difco) medium, minimal glucose medium (Cannon, 1984) and nitrogen-free Davis and Mingioli medium (NFDM medium) (Cannon, 1984), supplemented when required with histidine (at $\left.25 \mathrm{~g} \mathrm{ml}^{-1}\right)$ and $\mathrm{NH}_{4} \mathrm{Cl}(15 \mathrm{mM})$. Where indicated, plates were incubated anaerobically in a Gas Pak system (Becton Dickinson). Antibiotics for $E$. coli and for $K$. pnuemoniae were added at the following concentrations ( $\mu \mathrm{g}$ $\mathrm{ml}^{-1}$ ) respectively: chloramphenicol, 15 and 40 ; ampicillin, 100 and 200; carbenicillin, 150 and 200-300; tetracycline, 15 and 15; streptomycin, 250 and 250 for high copy-number plasmid selection, 40 and 40 (with chloramphenicol) for suicide vector selection (see below). For chromosomal selection, streptomycin and spectinomycin for $K$. pneumoniae were added at $15 \mu \mathrm{g} \mathrm{ml}^{-1}$ each. NAAZ medium was a freshly poured nutrient agar plate containing $0.16 \mathrm{mM} \mathrm{NaN}_{3}$ and $0.24 \mathrm{mM} \mathrm{ZnSO}_{4}$ (Hill et al., 1990). Anaerobic glucose-limited growth was achieved after 12-16 h of bubbling with $\mathrm{N}_{2}$ (about $50 \mathrm{ml} \mathrm{min}^{-1}$ ) at $28^{\circ} \mathrm{C}$ in $100 \mathrm{ml} \mathrm{NFDM}$ medium (Cannon, $1984)$, containing glucose $(0.25 \%, \mathrm{w} / \mathrm{v})$, twice the normal phosphate concentration, the trace elements of Poole et al. (1979), vitamin-free Casamino acids $\left(800 \mu \mathrm{g} \mathrm{ml}^{-1}\right)$ and histidine $\left(25 \mu \mathrm{g} \mathrm{ml}^{-1}\right)$. Exhaustion of glucose was detected by Clinistix (Miles Laboratories) and growth was estimated either by eye for solid media or by $\mathrm{OD}_{540}$; protein concentration was measured by using the BCA reagent (Pierce) in microdilution plates (Smith et al., 1990).

DNA manipulations. Bacterial strains and plasmids used in this study are listed in Table $1 . K$. pneumoniae chromosomal DNA was purified essentially as described by Robson et al. (1984). A gene library of K. pneumoniae (M5aI) was prepared and screened using the $c y d A B$ genes of $E$. coli by the procedure described previously (Moshiri et al., 1991a). The Wizard miniprep DNA purification system (Promega) was used for small-scale plasmid isolation from E. coli strain JM109. Largescale plasmid preparation was by the alkaline lysis method, DNA manipulations, transformation of E. coli, and agarose gel electrophoresis were done as described by Sambrook et al. (1989). Probes for Southern blotting were labelled with $[\alpha-$ $\left.{ }^{32} \mathrm{P}\right] \mathrm{dCTP}$ and random hexamers using the Prime-a-Gene kit (Promega). Single- and double-stranded DNA was sequenced using the Sequenase version $2.0 \mathrm{kit}$ (USB) with the 7-deazadGTP nucleotide mixtures, using specific custom-made primers. Separation of sequence transcripts by electrophoresis employed a modified acrylamide, Long Ranger (ATandT Biochem). Oligonucleotide primers were synthesized, with the trityl group attached, using a model 391 PCR-MATE DNA 
Table 1. Bacterial strains and plasmids

\begin{tabular}{|c|c|c|}
\hline Strain or plasmid & Relevant characteristics & Source/reference \\
\hline \multicolumn{3}{|l|}{ Strains } \\
\hline \multicolumn{3}{|l|}{ E. coli } \\
\hline JM109 & \multicolumn{2}{|l|}{$\begin{array}{l}\text { end } A \text { recA1 hsdR } 17 \Delta(\text { lac-pro } A B)\left[\mathrm{F}^{\prime}\right. \\
\left.\text { recA13 pro } A B \text { lacl }^{\mathrm{q}} \mathrm{Z} \Delta \mathrm{MI} 5\right]\end{array}$} \\
\hline \multicolumn{3}{|l|}{ K. pneumoniae } \\
\hline M5a1 & \multicolumn{2}{|l|}{ Wild-type } \\
\hline UNF122 & bisD2 $\Delta l a c 2002$ bsdR1 if $^{+} \mathrm{rec}^{+}$ & R. Dixon \\
\hline UNF3504 & hisD2 $\Delta$ lac2002 hsdR1 nif $^{+}$rec $^{+}$cydA1:: $\Omega$ & This work \\
\hline \multicolumn{3}{|l|}{ Plasmids } \\
\hline pHP45 & $\Omega$-fragment-containing plasmid & Prentki \& Kirsch (1984) \\
\hline pKAB & $\begin{array}{l}\text { K. pneumoniae cydAB cloned on } \\
\text { HindIII-Xhol fragment in pBluescript }\end{array}$ & This work \\
\hline pMM46 & $\begin{array}{l}\text { Suicide vector with temperature-sensitive } \\
\text { replication origin }\end{array}$ & Paul \& Merrick (1989) \\
\hline $\mathrm{pNG} 2$ & E. coli $c y d A B$ & Green et al. (1984) \\
\hline pNIKA1 & $\begin{array}{l}1.6 \mathrm{~kb} \text { PCR product carrying } \mathrm{Kp} c y d A \text { in } \\
\text { Hincll site of pTZ19 }\end{array}$ & This work \\
\hline $\mathrm{pNJ3}$ & $\begin{array}{l}\text { SacI-Sall cydA:: } \Omega \text { fragment from pNSJ2 } \\
\text { cloned in the Hincll site of pMM46 }\end{array}$ & This work \\
\hline pNSJ2 & $\begin{array}{l}\Omega \text { fragment from pHP45 in BamHI site of } \\
\text { pTRJ1 }\end{array}$ & This work \\
\hline pTRJ1 & $\begin{array}{l}\text { Pstl-Xbal cydA fragment from pNIKA1 } \\
\text { cloned in pBluescript }\end{array}$ & This work \\
\hline pTZ19 & $\mathrm{Cb}^{\mathrm{r}}$ & Stratagene \\
\hline
\end{tabular}

synthesizer on a $40 \mathrm{nmol}$ scale. The synthetic DNA was purified using oligonucleotide purification cartridges (Applied Biosystems). DNA fragments were cloned into M13mp18 and M13mp19, to facilitate sequencing of both strands. The sequence was also confirmed in both directions by automated DNA sequencing on a Li-Cor model 4000 automated DNA sequencer, using IRD41 fluorescently labelled primers (MWG$\mathrm{BIOTECH}$ ) and a thermocycler (Hybaid). DNA and protein sequences were analysed using PC/Gene (IntelliGenetics) and compared with sequences in the GenBank, SWISS-PROT and Prosite databases using the FASTA and BLAST programmes (Altschul et al., 1990; Pearson \& Lipman, 1988).

PCR procedures. PCR amplification reactions consisted of 100 pmol of each primer, $200 \mu \mathrm{M}$ dNTPs, $10 \mathrm{mM} \mathrm{KCl}, 2 \mathrm{mM}$ Tris/ $\mathrm{HCl}, \mathrm{pH} 8.5,0.25 \mathrm{mM} \mathrm{MgCl}_{2}, 0.04 \mathrm{mg}_{\text {gelatin } \mathrm{ml}^{-1}, 2.5}$ units Taq DNA polymerase and approximately $1 \mathrm{ng}$ template DNA (in $100 \mu$ l final volume), using a Hybaid thermocycler. Reactions used 30 cycles each consisting of $1 \mathrm{~min}$ at $93^{\circ} \mathrm{C}$, $1 \mathrm{~min}$ at $55^{\circ} \mathrm{C}$ and $5 \mathrm{~min}$ at $72^{\circ} \mathrm{C}$. Templates for the reaction were chromosomal DNA (1 ng) from $K$. pneumoniae strains UNF122 or M5aI. Primers (based on the E. coli sequence) were designed to be complementary to the $5^{\prime}$ start of the $c y d A$ gene on one strand (GGGGTACCCGGGAGCAAGGAGTCATGATGTTAGATATAGTC) and to the $3^{\prime}$ end of the $c y d A$ gene on the complementary strand (CGGGATCCCCGGGTACTTCATAATCGATCAT). Restriction sites to facilitate cloning were included in each primer: KpnI and $S m a I$ for the first primer and SmaI and BamHI for the second.

Hydrogen evolution and nitrogenase assays. Measurements of $\mathrm{H}_{2}$ evolution and $\mathrm{C}_{2} \mathrm{H}_{2}$ reduction (as a measure of nitrogenase activity) were made in Suba-seal capped serum bottles as described previously (Hill et al., 1990), using cell suspensions $\left(0.08 \mathrm{mg}\right.$ protein $\left.\mathrm{ml}^{-1}\right)$ in $0.5 \mathrm{ml}$ saline phosphate buffer (Cannon, 1984) that had been anaerobically harvested, washed and re-suspended in the same buffer. Incubations were at $30^{\circ} \mathrm{C}$, with $50 \mathrm{mM}$ substrate, in a shaking water-bath, and were terminated after $15 \mathrm{~min}$ incubation by injecting $0.2 \mathrm{ml}$ $30 \%(\mathrm{w} / \mathrm{v})$ trichloroacetic acid. Gas samples $(0.5 \mathrm{ml})$ were analysed by gas chromatography (Hill et al., 1990). Respiration was measured using the same cell suspensions $\left(0.03 \mathrm{mg}\right.$ protein $\left.\mathrm{ml}^{-1}\right)$ in $2.5 \mathrm{ml}$ saline phosphate buffer in a Clark-type $\mathrm{O}_{2}$ electrode chamber (Rank Bros) at $30^{\circ} \mathrm{C}$ with $50 \mathrm{mM}$ substrates. Rates of $\mathrm{O}_{2}$ uptake were calculated assuming that the $\mathrm{O}_{2}$ concentration in air-saturated saline phosphate buffer is $240 \mu \mathrm{M}$; no $\mathrm{O}_{2}$ consumption occurred in the absence of added susbtrate. All experiments were performed at least twice.

Spectrophotometry. Spectra of washed cell suspensions (0.5-1.5 mg protein $\left.\mathrm{ml}^{-1}\right)$ were recorded using a Shimadzu UV-3000 dual-wavelength spectrophotometer. A $2 \mathrm{~nm}$ band width, a $10 \mathrm{~mm}$ light path and a scan speed of $100 \mathrm{~nm} \mathrm{~min}{ }^{-1}$ were used to obtain the sodium-dithionite-reduced-minusoxidized difference spectra at room temperature.

\section{RESULTS AND DISCUSSION}

\section{Cloning of the cydAB region of $K$. pneumoniae}

Cytochrome $b d^{\prime}$ from $K$. pneumoniae is very similar to that of $E$. coli, so the sequence of the $E$. coli cydAB genes could be used in strategies for cloning the genes from $K$. pneumoniae. PCR was used to generate a DNA fragment of about $1.6 \mathrm{~kb}$, a size equal to the $E$. coli $c y d A$ gene, using K. pneumoniae M5a1 (wild-type) chromosomal 
(a)

xpcyda

Eccyda

EcAppC

HicyoI

ArCydA

S sCydA

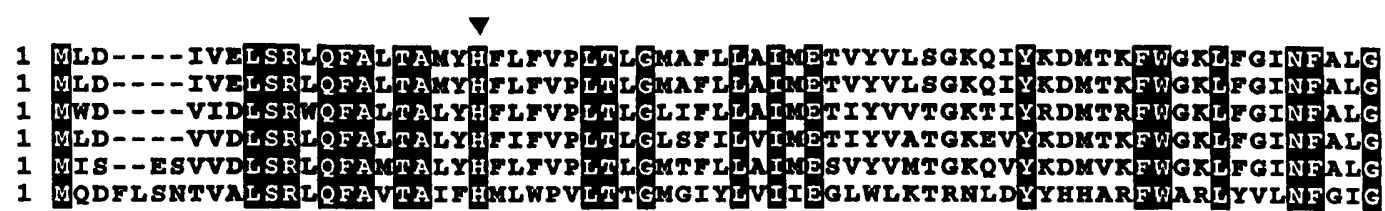

xpcydA

eccydx

Ecגppc

Hicyor

AvcydA

Sacyda

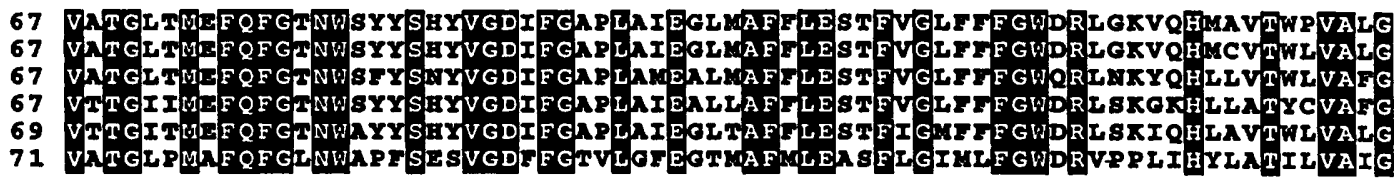

KpcydA

Eccyda

EcגppC

B1CYOI

AvCydA

SBCydA

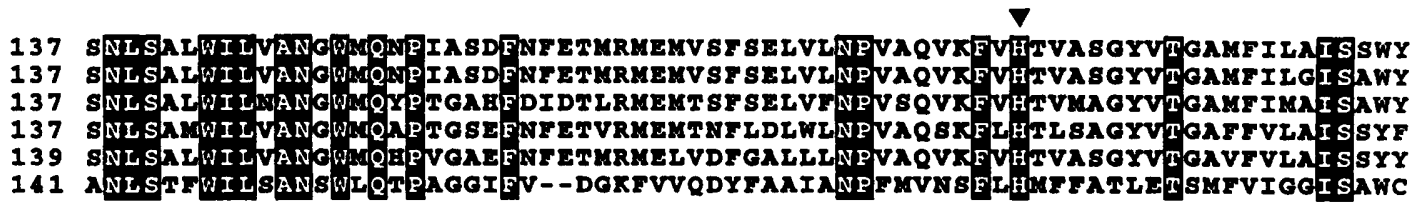

xpcyda ecCydA EcAppC

HiCyoI

Arcyda

SaCydA

207 MEKGRDFAFAKRSFAIAAGFGKAAILSVIVLGDESGYEMGDVQXIKLAAIEAEWET'PA- - PAAFTLFGI

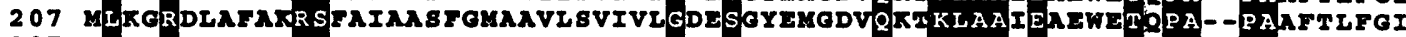
207 LLRGRERWVALRSFAIGSVFGTLAI IGTLQLGDSSAYEVAQVQPVKLAAWEOEWQTEPA--PAPFHVVAW 207 LLKGRDFEFARSF SVAATFGFIASISVLILGDESOYDIGKAQPVKLAAULAEF ETEPA- -PAPFLPVAI

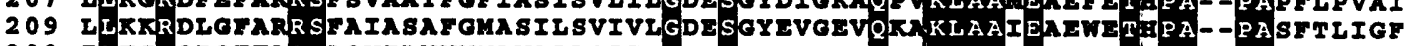
209 ILTGRQPQF FAR SQVILVVVMAVAPLQIFIGBLSAEQVSVHQPAKLAAWEALWETPAKTEAAWSVVAL

KPCYAA 275 PDQRRR-RTFAIQIPFALGIIAT--RSVDKQVTGLKALMVQHEERIRNGMKAYALLEQLRA-D---GSTD

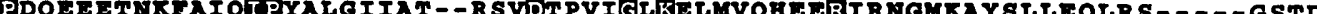

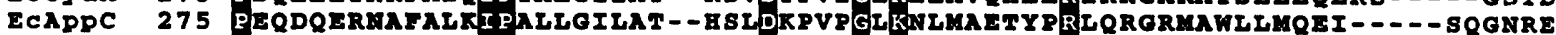
HICYOI 275 PNTAEKKNDFAIEI PYLGGVIAT--RSIDKEIIGLKDLQALNETRVR SGIRAYELFTQLRAEKKANGQVN AVCYAA 277 PNEEEQRTDEAVXI PWVLGIIAT--RSLDEQVIGIKDLIADHEARIRNGKVRYGLLEELRA----GNKS

SBCYAA 279 PNDKAEXNDKEISI PGALSYILELKPQLDKPIOGLKDWAPVDRPRM - _ . . . .

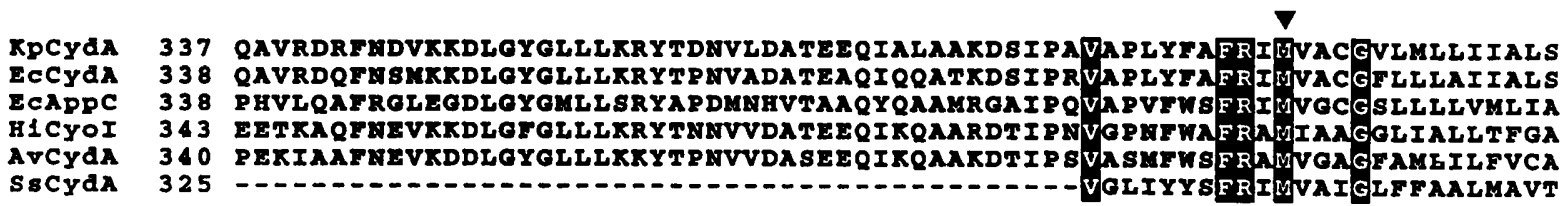

KPCYdA 407 FWSVIRNR-----IGEKKWLLAAAFYGLPLPWIAVESGWFVAEYGRQPWAIGEVLPTAVANSSLTAGDLI ECCYAA 408 FWSVIRAR----IGEKKWLERAALYGIPLPWIAVEAGWEVAEYGRQPWAIGEVLPTAVANSSLTAGDI ECAPPC 408 LVQTLREK----IDQBRWVLKMALWSIPLPWIAIEAGWFUTEFGRQPWAIQDILPTY SAHSALTTGQLA H1CYOI 113 FVQNLRWX---.-VTQIPLLLKVLLWGLPLPWIAIECGWFLAEYGRQP WATYEILPVOVSASNL STGDLW AVCYAA 110 FWASARKA-----EESKPWLEKFALYSLPLPWIATTGWFVAEHGRQPWTIGGVLPTHLSASSLSTGDLW SBCYAA 350 VLQWLRGKLKPEIISQQKWLLRAWVEAAPLGYLAVETGWIVRCVGRQPWIVYGEMRTAESASNLPPGEIL

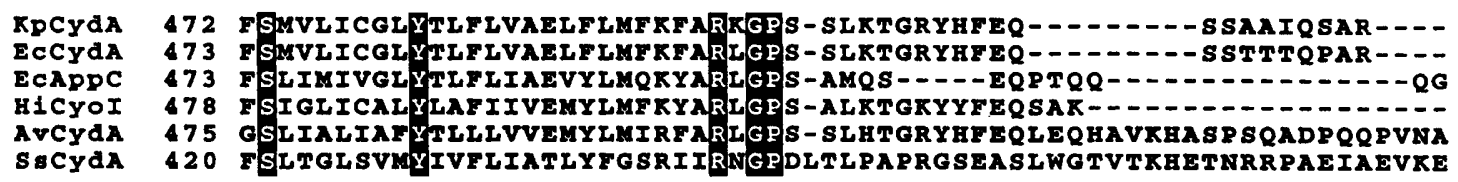

Fig. 1. For legend see facing page.

DNA as template and primers designed to be complementary to the $5^{\prime}$ (including the Shine-Dalgarno sequence) and $3^{\prime}$ ends of the coding region of the E. coli cydA gene. Using the Smal sites incorporated in the primers, the K. pneumoniae PCR product was cloned into the HinclI site of pTZ19 to yield pNIKA1. Subsequently the presumptive $K$. pneumoniae cydA gene was excised from pNIKA1 with PstI and XbaI, and cloned into pBluescript SK + to yield pTRJ1. It subsequently proved impossible to clone $c y d B$ separately 

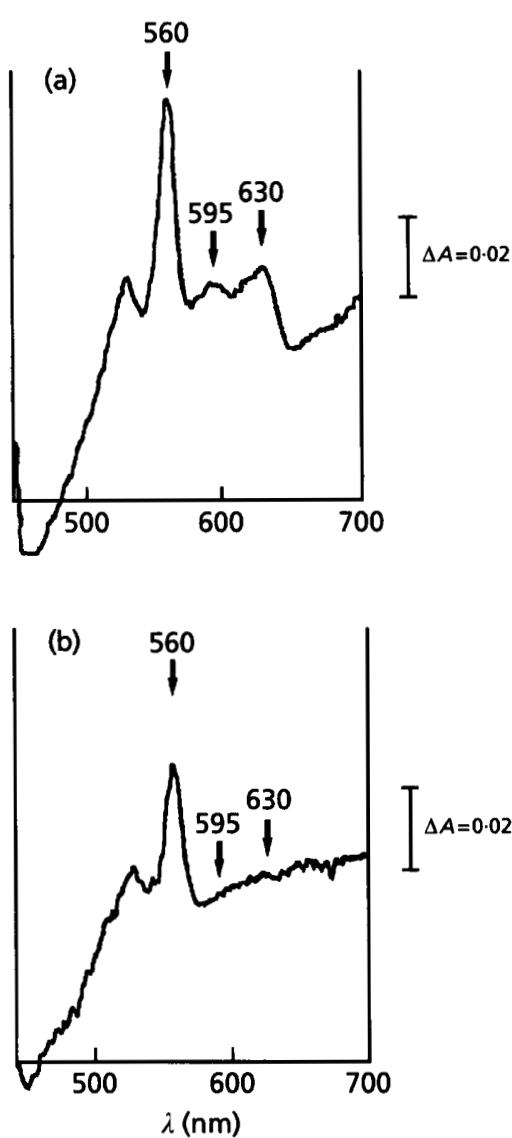

Fig. 2. Dithionite-reduced-minus-oxidized difference spectra of whole cells of $K$. pneumoniae, strains (a) UNF122 $\left(c y d^{+}\right)$and (b) UNF3504 (cyd). Cells were grown in air to stationary phase (in LB medium), harvested, washed and resuspended (see Methods). They were reduced with dithionite or oxidized with $\mathrm{O}_{2}$. The $\mathrm{cyd}^{+}$strain (UNF122) showed the presence of cytochrome $b d^{\prime}$ as seen by the characteristic absorbance at $560 \mathrm{~nm}, 595 \mathrm{~nm}$ and $630 \mathrm{~nm}$. The cyd strain (UNF3504) showed no haem $b_{595}$ or haem $d(630 \mathrm{~nm})$ by these criteria. The peak at $560 \mathrm{~nm}$ is due to the presence of other b-type haems. The protein concentrations ( $\mathrm{mg} \mathrm{ml}^{-1}$ ) were 0.77 for UNF3504 and 1.03 for UNF122. Spectra were measured at room temperature.

Conservation in all five sequences supports conclusions from previous alignments of CydA and $\mathrm{CydB}$ of E. coli and A. vinelandii (Moshiri et al., 1991a; Kaysser et al., 1995) and from site-directed mutagenesis (Fang et al., 1989; Kaysser et al., 1995) which indicated that in CydA His 19, His 186 and Met 393 (marked in Fig.1a) provide three of the four axial ligands to the $\mathrm{Fe}$ of the three haems in the oxidase complex (numbers refer to E. coli residues). In E. coli an 11 amino acid stretch (Lys 254 to Thr 263) contains the epitope for two inhibitory monoclonal antibodies and has been proposed to form part of a functional domain in which ubiquinol is oxidized (Dueweke \& Gennis, 1990). In K. pneumoniae this region in CydA is also highly conserved. One other sequence encoding a potential CydA protein was identified as part of a $4.5 \mathrm{~kb}$ genomic fragment from Halobacterium salinarium (EMBL accession no. 1070344). This sequence contains a truncated open reading frame that encodes the first 160 amino acids of a protein with $33 \%$ identity to $E$. coli CydA.

Analysis of the multiple alignment of CydA sequences shown in Fig. 1(a) for predicted transmembrane helices using PHDhtm (Rost et al., 1995) identified seven distinct transmembrane domains which are entirely consistent with the previously proposed topological model for subunit I (see Kaysser et al., 1995). In this model the interhelical periplasmic domain (Gly 238 to Ile 392), called the Q-loop, between helices $\mathrm{E}$ and $\mathrm{F}$ has been proposed to constitute a functional domain near the periplasmic surface of the membrane and close to haem $b_{558}$ (Dueweke \& Gennis, 1990; Kaysser et al., 1995). Whilst the role of the proteins encoded by the Synechocystis sp. cydAB genes is only inferred by homology it is of interest to note that the Synechocystis sp. CydA protein lacks almost half this domain (equivalent to residues Arg 319 to Arg 382 in E. coli CydA, see Fig. 1a).

\section{Construction of a chromosomal mutation in cyd by in vitro mutagenesis}

The plasmid pTRJ1 was used as a vehicle to insert the omega fragment $(\Omega)$ into the $K$. pneumoniae chromosomal $c y d A$ gene. This fragment, encoding resistance to streptomycin and spectinomycin, is flanked by signals for termination of transcription and translation (Prentki \& Kirsch, 1984). It was released from $\mathrm{pHP} 45$ by digestion with $B a m \mathrm{HI}$ and cloned into the $\mathrm{BamHI}$ site in the $c y d A$ insert of pTRJ1 to yield pNSJ2. Subsequently, the SacI-SalI cydA:: $\Omega$ fragment of pNSJ2 was bluntended and cloned into the HincII site of the temperaturesensitive suicide vector pMM46 (Paul \& Merrick, 1989) to yield $\mathrm{pNJ} 3$. This plasmid carries a temperaturesensitive origin of replication and the resistance gene for chloramphenicol as well as the $\Omega$ fragment. Transformants of UNF122 with pNJ3 were initially selected for resistance to chloramphenicol, streptomycin and spectinomycin, and were then sequentially subcultured (six times) at $41^{\circ} \mathrm{C}$ in $\mathrm{LB}$ medium containing streptomycin and spectinomycin to prevent selection of spontaneously resistant colonies. Between subcultures, clones were checked for sensitivity to chloramphenicol (at $30^{\circ} \mathrm{C}$ ) and one clone (strain UNF3504) that was resistant to streptomycin and spectinomycin but sensitive to chloramphenicol was selected. To confirm that a double cross-over event had occurred (insertion of the mutant plasmid DNA into the $K$. pneumoniae chromosome) UNF3504 was compared with the wild-type strain (UNF122) by Southern blot analysis using the $c y d A$ PCR fragment as a probe. Using genomic digests with Asp718, EcoRI or PstI a single hybridizing band which was $2 \mathrm{~kb}$ larger in UNF3504 than in UNF122 was identified in each case (data not shown). The cydA:: $\Omega$ mutant was also screened for the ability to grow on NAAZ medium (which contains azide and thus inhibits the o-type oxidase). As predicted this medium did not support growth of the cydA:: $\Omega$ mutant because it lacks the alternative oxidase. 
Table 2. Anaerobic activities and potential respiratory activities of $K$. pneumoniae $\mathrm{Cyd}^{+}$and $\mathrm{Cyd}^{-}$strains

All activities were measured on glucose-depleted, anaerobically grown washed cells supplied with $50 \mathrm{mM}$ substrates. Results are mean $\pm \mathrm{SE}$. Figures in parentheses are numbers of replicates.

\begin{tabular}{|c|c|c|c|c|c|c|c|}
\hline \multirow[t]{3}{*}{ Strain } & \multirow{3}{*}{$\begin{array}{c}\text { Cyd } \\
\text { phenotype }\end{array}$} & \multicolumn{4}{|c|}{ Anaerobic activities } & \multirow{2}{*}{\multicolumn{2}{|c|}{$\begin{array}{l}\text { Potential respiratory } \\
\text { activities } \neq \text { with : }\end{array}$}} \\
\hline & & \multicolumn{2}{|c|}{ Nitrogenase* with: } & \multicolumn{2}{|c|}{$\mathrm{H}_{2}$ evolution $\dagger$ with: } & & \\
\hline & & Glucose & $\begin{array}{l}\text { Glucose }+ \\
\text { formate }\end{array}$ & Glucose & Formate & Glucose & Formate \\
\hline UNF122 & + & $83 \pm 7(4)$ & $87 \pm 6(4)$ & $334 \pm 14(2)$ & $638 \pm 51(2)$ & $95 \pm 5(5)$ & $72 \pm 15(3)$ \\
\hline UNF3504 & - & $67 \pm 6(4)$ & $75 \pm 10(4)$ & $92 \pm 6(2)$ & $229 \pm 28(2)$ & $37 \pm 3(5)$ & $39 \pm 6(3)$ \\
\hline
\end{tabular}

* Measured as $\mathrm{C}_{2} \mathrm{H}_{2}$ reduction: $\mathrm{nmol} \mathrm{C}_{4} \mathrm{H}_{4}$ produced $\min ^{-1}$ (mg protein) ${ }^{-1}$.

†nmol $\mathrm{H}_{2}$ evolved $\min ^{-1}$ (mg protein) ${ }^{-1}$.

$\ddagger \mathrm{nmol} \mathrm{O} \mathrm{O}_{2}$ consumed $\min ^{-1}$ (mg protein $)^{-1}$.

\section{Confirmation that strain UNF3504 lacks cytochrome bd'}

The failure of UNF3504 to grow on the medium containing zinc azide is consistent with the lack of an active cytochrome $b d^{\prime}$ and this has been confirmed by studies of cell suspensions of the mutant. Packed cells of the wild-type strain UNF122, either grown in Luria Broth to late stationary phase, or grown anaerobically in glucose-depleted cultures, were green in colour indicating the presence of the $b d$-type oxidase. This green colouration was absent in the packed cells of strain UNF3504, which were light pink in colour, indicating that the mutant lacks the oxidase. This was consistent with the reappearance of the green colour in strain UNF3504 when transformed with either the K. pneumoniae $c y d^{+}$plasmid (pKAB) or the E. coli $c y d^{+}$ plasmid (pNG2). Spectroscopic examination of the $c y d^{+}$ bacteria demonstrated the presence of cytochrome $b d^{\prime}$ as shown by the peak at $630 \mathrm{~nm}$ which was absent from strain UNF3504 (Fig. 2).

\section{Activities of anaerobically grown washed cells}

The $c y d A$ mutant was able to grow under anaerobic conditions, either diazotophically or with excess $\mathrm{NH}_{4}^{+}$, at similar growth rates to the wild-type strain (UNF122); growth was measured under the following conditions: on solid NFDM medium with or without an excess of $\mathrm{NH}_{4} \mathrm{Cl}$ in a gas pack anaerobic jar, in liquid NFDM medium containing glucose (excess or limiting) and bubbled with $\mathrm{N}_{2}$ (see Methods).

When cells harvested from the anaerobic glucosedepleted cultures were assayed anaerobically the nitrogenase activities of the $c y d^{+}$and $c y d$ strains were not markedly different (Table 2). The rate of hydrogen evolution supported by glucose gives a measure of the total electron flux arising from glucose fermentation, whereas that supported by formate indicates the potential electron flow through the formate hydrogen lyase complex. In both strains, the rate of $\mathrm{H}_{2}$ evolution from formate was about twice that from glucose (Table 2); in the cyd strain rates with both substrates were about a third of that measured in the wild-type (Table 2). Because the anaerobic growth of the mutant is not impaired, these lower rates of $\mathrm{H}_{2}$ evolution in the mutant may indicate that the $b d$-type oxidase has a role in protecting $\mathrm{O}_{2}$-sensitive processes during harvesting and washing procedures. Oxygen-sensitive fermentation enzymes include pyruvate formate-lyase, an important component of the fermentation pathway, and formate hydrogenlyase. Recently, an additional role for the $E$. coli oxidase has been proposed, to prevent the build-up of diffusible oxygen radicals (Goldman et al., 1996). Such a role in $K$. pneumoniae may account for the poorer anaerobic $\mathrm{H}_{2}$-evolving activity in the $c y d$ mutant (UNF3504) compared to that of the wild-type (UNF122) (see Table 2), if such radicals were produced during the harvesting and washing procedures. Potential respiration rates with either glucose or formate as substrate were lower in the cyd strain UNF3504 than in wild-type UNF122 (Table 2). This difference is consistent with strain UNF3504 failing to make one of the two terminal oxidases, which was confirmed by spectroscopic examination of these anaerobically grown bacteria (data not shown).

\section{Role of the cytochrome bd' in removal of inhibitory oxygen}

To determine the effect of microaerobiosis on nitrogense activity in the glucose-depleted cells, nitrogenase activity was measured in the presence of very low levels of $\mathrm{O}_{2}$. Activity supported by glucose was markedly more inhibited by $\mathrm{O}_{2}$ in the $c y d$ strain than the wild-type (Fig. $3 \mathrm{a})$. For example, at $1.24 \mathrm{kPa} \mathrm{O}$ there was only $60 \%$ in the wild-type but complete inhibition in the mutant lacking cytochrome $b d^{\prime}$. For nitrogenase activity lowpotential electrons are required, these being supplied by the activity of pyruvate: flavodoxin oxidoreductase. For this reason, although formate is a potential electron donor for the respiratory chain (Table 2), it does not support nitrogenase activity. However, when formate was included together with glucose, at $1.24 \mathrm{kPa} \mathrm{O}_{2}$, a 


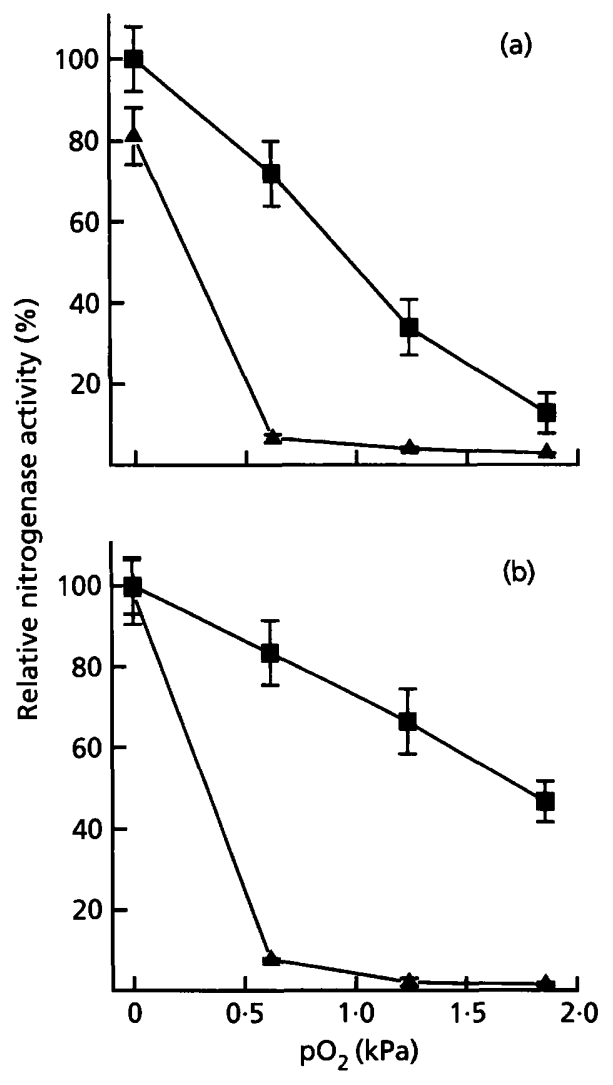

Fig. 3. Effect of $\mathrm{O}_{2}$ on nitrogenase activity in $K$. pneumoniae strains, UNF122 (cyd $\left.d^{+}, \square\right)$ and UNF3504 (cyd, A). (a) Nitrogenase activity supported by glucose alone. (b) Nitrogenase activity supported by glucose plus formate. Activity is shown as the percentage of the activity of the $\mathrm{cyd}^{+}$strain, under anaerobiosis (see Table 2).

twofold stimulation of nitrogenase activity was seen in the wild-type organism but not in the cyd mutant (Fig. 3 ). Thus, electrons derived from a formate dehydrogenase under these microaerobic conditions probably pass to the branch of the respiratory chain terminating in the $b d$-type oxidase. By analogy with studies using $E$. coli, formate dehydrogenase-O is likely to be the enzyme involved (Sawers, 1994; Bock \& Sawers, 1996). In all these experiments, the only factor affecting the dissolved $\mathrm{O}_{2}$ is the rate of respiration. This was lower in the $c y d$ strain than in the wild-type using either glucose or formate as substrate (Table 2). Therefore we conclude that in vivo the $b d$-type oxidase of $K$. pneumoniae is involved in preventing inhibition of nitrogenase activity by removing molecular $\mathrm{O}_{2}$.

$\mathrm{H}_{2}$ evolution from either glucose or formate was measured as an indication of flux through the fermentative pathways (Fig. 4). The proportion of $\mathrm{H}_{2}$ evolution expected to arise from nitrogenase activity under these assay conditions is small (Hill, 1976b). Some enzymes in these fermentative pathways are oxygensensitive as shown by the inhibition of hydrogen evolution by low concentrations of oxygen (Fig. 4a). In the wild-type organism, $\mathrm{O}_{2}$ inhibition occurred with

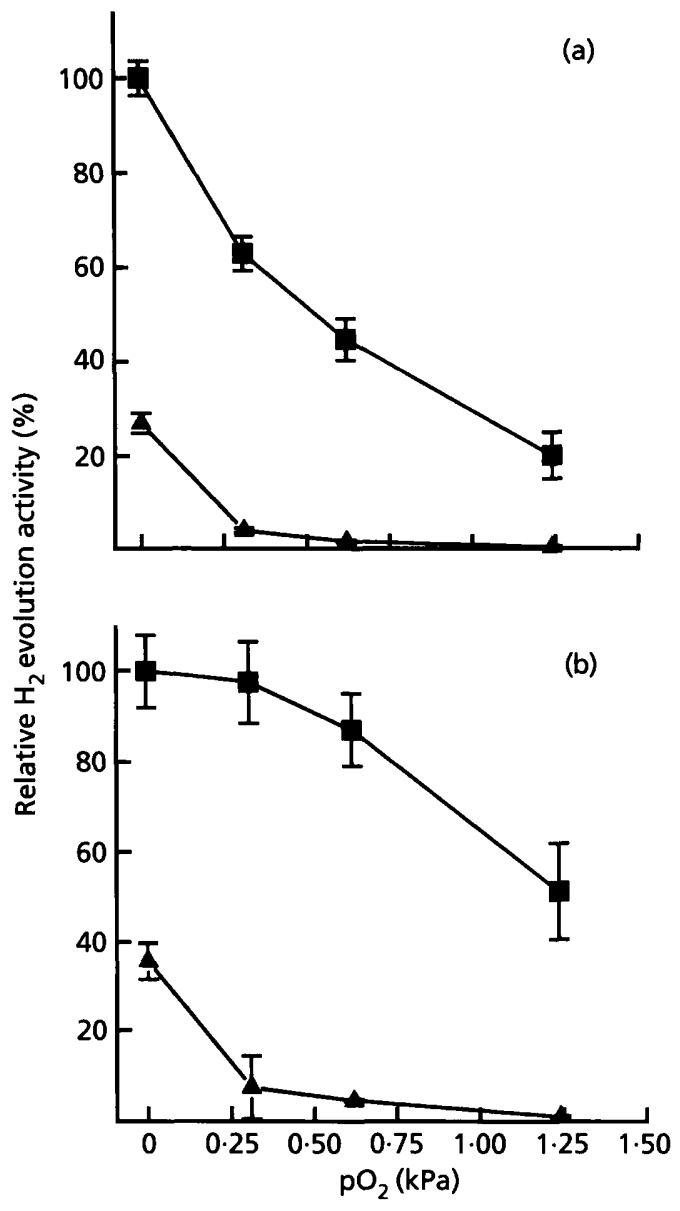

Fig. 4. Effect of $\mathrm{O}_{2}$ on $\mathrm{H}_{2}$-evolving activity in $K$. pneumoniae strains, UNF122 (cyd $\left.{ }^{+}, \square\right)$ and UNF3504 (cyd, A). (a) $\mathrm{H}_{2}$-evolving activity supported by glucose alone. (b) $\mathrm{H}_{2}$-evolving activity supported by glucose plus formate. Activity is shown as the percentage of the activity of the $c y d^{+}$strain, under anaerobiosis (see Table 2).

both glucose and formate but it was considerably less pronounced with formate. By contrast, in the $c y d$ strain inhibition by oxygen was far more severe and was the same with both substrates. This marked difference in the inhibition by $\mathrm{O}_{2}$ of $\mathrm{H}_{2}$ evolution in the mutant compared with the wild-type suggests that the $b d$-type oxidase has a role in protecting $\mathrm{O}_{2}$-labile enzymes such as formate hydrogenlyase and pyruvate formate-lyase as well as nitrogenase. The particular effectiveness of formate in protecting against oxygen inhibition is consistent with the presence of an electron transport chain in which formate dehydrogenase-O is coupled to the $b d$-type oxidase.

Comparison of the data in Figs 3(a) and 4(a) indicates that the enzymes involved in $\mathrm{H}_{2}$ evolution are apparently more sensitive to $\mathrm{O}_{2}$ than is nitrogenase, consistent with a previous observation (Hill et al., 1984). Differences in the degree of exposure to $\mathrm{O}_{2}$ due to the location of these enzymes may be the reason; the formate hydrogenlyase complex is membrane bound (Sawers, 1994) whereas the nitrogenase is soluble within the cytoplasm. Further, 


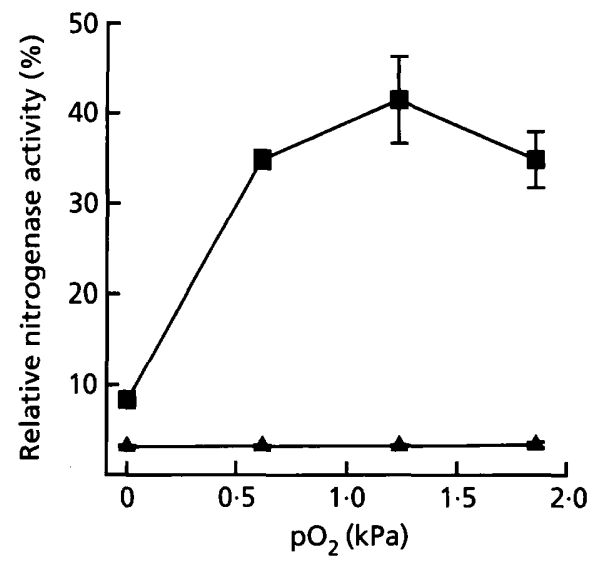

Fig. 5. Effect of $\mathrm{O}_{2}$ on nitrogenase activity in $K$. pneumoniae strains, UNF122 (cyd $\left.d^{+}, \square\right)$ and UNF3504 (cyd, A), supported by formate plus pyruvate. Activity is shown as the percentage of the activity of the $\mathrm{cyd}^{+}$strain, under anaerobiosis (see Table 2).

nitrogenase can reduce low concentrations of $\mathrm{O}_{2}$ to water without loss of $\mathrm{C}_{2} \mathrm{H}_{2}$-reducing activity; this process could have an autoprotective function (Thorneley \& Ashby, 1989).

\section{Role of the bd-type oxidase in energy conservation}

In the absence of added glucose, nitrogenase activity in samples from anaerobic glucose-limited chemostats of $K$. pneumoniae is dependent upon the presence of low levels of $\mathrm{O}_{2}$ (Hill, 1976a). Such behaviour is consistent with fermentation products supporting microaerobic respiration to provide the necessary ATP. The required low-potential electrons arise from the activity of a nifspecific pyruvate:flavodoxin oxidoreductase, the pyruvate being a glycolytic product. Consistent with this dual requirement, no $\mathrm{O}_{2}$-dependent nitrogenase activity was observed in the presence of either formate or pyruvate in wild-type or mutant strains lacking cytochrome $b d^{\prime}$ (data not shown). Thus in this situation the pyruvate can only provide electrons for nitrogenase and formate oxidation can provide the necessary ATP. By contrast, providing formate together with pyruvate resulted in significant $\mathrm{O}_{2}$-dependent nitrogenase activity in the wild-type strain (Fig. 5). In the cyd strain, however, no $\mathrm{O}_{2}$-dependent nitrogenase activity was observed with pyruvate plus formate (Fig. 5). We conclude, therefore, that in $K$. pneumoniae the $b d$-type oxidase is essential for $\mathrm{O}_{2}$-dependent nitrogenase activity in which formate dehydrogenase- $\mathrm{O}$ may play a part in energy conservation.

\section{Conclusions}

The homology of the deduced amino acid sequences of the subunits of the cytochrome $b d^{\prime}$ (CydA and CydB) of $K$. pneumoniae with those of E. coli is high, which is not surprising in view of the similarity of these oxidases (Smith et al., 1990; Kita et al., 1984) and their occurrence under anaerobic and microaerobic conditions (Smith et al., 1990; Tseng et al., 1996). The alignments of the CydA and $\mathrm{CydB}$ sequences with other similar pairs of proteins - CydA and $\mathrm{CydB}$ from E. coli, A. vinelandii and Synechocystis sp., E. coli AppC and AppB, and $H$. influenzae CyoA and $\mathrm{CyoB}$ (see Fig. 1) - indicates that they all possess the same presumptive three axial ligands for haem binding in subunit I, and a region of high homology that has been proposed as an ubiquinolbinding site. The latter sequence in $K$. pneumoniae, $E$. coli and $A$. vinelandii is precisely conserved, so the architecture of this site is unlikely to be responsible for the markedly higher $k_{\text {cat }}$ of the $A$. vinelandii enzyme (Jünemann et al., 1995).

This work has identified two roles for the $b d$-type oxidase of $K$. pneumoniae. These are the conservation of energy under microaerobic conditions and the protection of anaerobic processes from inhibition by $\mathrm{O}_{2}$. Furthermore, the work has revealed a probable specific function for formate dehydrogenase- $\mathrm{O}$ in microaerobic catabolism. Formate oxidation, by way of this enzyme, is apparently able to provide electrons for an electron transport chain terminating in the high-affinity $b d$-type oxidase, which plays a part in energy conservation (ATP synthesis) and the removal of inhibitory $\mathrm{O}_{2}$.

\section{ACKNOWLEDGEMENTS}

N.S. J. held an AFRC cooperative studentship. S.H. and M.J.M. acknowledge support from the BBSRC through a grant-in-aid to the John Innes Centre. F.M. acknowledges support from the US Department of Agriculture (NRICGP grant 95-37305-6538) and thanks Cheryl Maier for help with sequence analysis.

\section{REFERENCES}

Altschul, S. F., Gish, W., Miller, W., Myers, E. W. \& Lipman, D. J. (1990). Basic local alignment search tool. J Mol Biol 215, 403-410.

Anraku, Y. \& Gennis, R. B. (1987). The aerobic respiratory chain of Escherichia coli. Trends Biochem Sci 12, 262-266.

Bishop, P. E. \& Premakumar, R. (1992). Alternative nitrogen fixation systems. In Biological Nitrogen Fixation, pp. 736-762. Edited by G. Stacey, R. H. Burris \& H. J. Evans. New York \& London: Chapman \& Hall.

Bock, A. \& Sawers, G. (1996). Fermentation. In Escherichia coli and Salmonella typhimurium: Cellular and Molecular Biology, 2nd edn, pp. 262-282. Edited by F. C. Neidhardt and others. Washington, DC: American Society for Microbiology.

Cannon, F. C. (1984). Genetic studies with diazotrophs. In Methods for Evaluating Biological Nitrogen Fixation, pp. 367-413. Edited by F. J. Bergersen. Chichester: Wiley.

Dassa, J., Fsihi, H., Marck, C., Dion, M., Kieffer-bontemps, M. \& Boquet, P. L. (1991). A new oxygen-regulated operon in Escherichia coli comprises the genes for a putative third cytochrome oxidase and for $\mathrm{pH} 2.5$ acid phosphatase (appA). Mol Gen Genet 229, 341-352.

D'mello, R., Hill, S. \& Poole, R. K. (1994). Determination of the oxygen affinities of the terminal oxidases in Azotobacter vinelandii using the deoxygenation of oxyleghaemoglobin and oxymyoglobin: cytochrome $b d$ is a low-affinity oxidase. Microbiology 140, 1395-1402.

D'mello, R., Hill, S. \& Poole, R. K. (1996). The cytochrome $b d$ 
quinol oxidase in $E$. coli has an extremely high oxygen affinity: implications for regulation of activity in vivo by oxygen inhibition. Microbiology 142, 755-763.

D'mello, R., Purchase, D., Poole, R. K. \& Hill, S. (1997). Expression and content of terminal oxidases in Azotobacter vinelandii grown with excess $\mathrm{NH}_{4}^{+}$are modulated by $\mathrm{O}_{2}$ supply. Microbiology 143, 231-237.

Dueweke, T. J. \& Gennis, R. B. (1990). Epitopes of monoclonal antibodies which inhibit ubiquinol oxidase activity of Escherichia coli cytochrome $d$ complex localize functional domain. $J$ Biol Chem 265, 4273-4277.

Dueweke, T. J. \& Gennis, R. B. (1991). Proteolysis of the cytochrome $d$ complex with trypsin and chymotrypsin localizes a quinol oxidase domain. Biochemistry 30, 3401-3406.

Fang, H. \& Gennis, R. B. (1993). Identification of the transcriptional start site of the cyd operon from Escherichia coli. FEMS Microbiol Lett 108, 237-242.

Fang, H., Lin, R.-J. \& Gennis, R. B. (1989). Location of heme axial ligands in the cytochrome $d$ terminal oxidase complex of Escherichia coli determined by site-directed mutagenesis. J Biol Chem 264, 8026-8032.

Fleischmann, J. and others (1995). Whole-genome random sequencing and assembly of Haemophilus influenzae Rd. Science 269, 496-512.

Goldman, B. S., Gabbert, K. K. \& Kranz, R. G. (1996). The temperature-sensitive growth and survival phenotypes of Escherichia coli cydDC and $c y d A B$ strains are due to deficiencies in cytochrome $b d$ and are corrected by exogenous catalase and reducing agents. J Bacteriol 178, 6348-6351.

Green, G. N., Kranz, J. E. \& Gennis, R. B. (1984). Cloning of the cyd gene locus coding for the cytochrome $d$ complex of Escherichia coli. J Bacteriol 32, 99-106.

Green, G. N., Fang, H., Lin, R.-J., Newton, G., Mathers, M., Georgiou, C. D. \& Gennis, R. B. (1988). The nucleotide sequence of the cyd locus encoding the two subunits of the cytochrome $d$ terminal oxidase complex of Escherichia coli. J Biol Chem 263, 13138-13143.

Hill, S. (1976a). Influence of the atmospheric oxygen concentration on acetylene reduction and efficiency of nitrogen fixation in intact Klebsiella pneumoniae. J Gen Microbiol 93, 335-345.

Hill, S. (1976b). The apparent ATP requirement for nitrogen fixation in growing Klebsiella pneumoniae. J Gen Microbiol 95, 297-312.

Hill, S. (1992). Physiology of nitrogen fixation in free-living heterotrophs. In Biological Nitrogen Fixation, pp. 87-134. Edited by G. Stacey, R. H. Burris \& H. J. Evans. New York \& London: Chapman \& Hall.

Hill, S. \& Kavanagh, E. (1980). Roles of nifF and nifJ gene products in electron transfer to nitrogenase in Klebsiella pneumoniae. J Bacteriol 141, 470-475.

Hill, S., Turner, G. L. \& Bergersen, F. J. (1984). Synthesis and activity of nitrogenase in Klebsiella pneumoniae exposed to low concentration of oxygen. J Gen Microbiol 130, 1061-1067.

Hill, S., Viollet, S., Smith, A. T. \& Anthony, C. (1990). Roles for enteric $d$-type cytochrome oxidase in nitrogen fixation and microaerobiosis. J Bacteriol 172, 2071-2078.

Hill, S., Kavanagh, E., Munn, J. A., Kahindi, J., Campbell, F., Yates, M. G., D'mello, R. \& Poole, R. K. (1995). Physiology of $\mathrm{N}_{2}$ fixation relating to $\mathrm{N}, \mathrm{O}_{2}$ and $\mathrm{H}_{2}$ status in free-living heterotrophs. In Nitrogen Fixation with Non-legumes, pp. 15-25. Edited by N. A. Hegazi, M. Fayez \& M. Monid. Cairo: The American University in Cairo Press.
Junemann, S., Butterworth, P. J. \& Wrigglesworth, J. M. (1995). A suggested mechanism for the catalytic cycle of cytochrome $b d$ terminal oxidase based on kinetic analysis. Biochemistry 34, 14861-14867.

Juty, N. S., Hill, S. \& Anthony, C. (1995). Isolation and characterization of a $c y d^{-}$mutant of Klebsiella pneumoniae. In Nitrogen Fixation: Fundamentals and Applications. Proceedings of the 10th International Congress on Nitrogen Fixation, St Petersburg, Russia, p. 216. Edited by I. A. Tikhonovich, N. A. Provorov, V. I. Romanov \& W. E. Newton. Dordrecht: Kluwer Academic. Kaneko, T. and others (1996). Sequence analysis of the genome of the unicellular cyanobacterium Synechocystis sp. PCC6803. II. Sequence determination of the entire genome and assignment of potential protein-coding regions. DNA Res 3, 109-136.

Kavanagh, E. P. \& Hill, S. (1990). The automatic maintenance of low dissolved oxygen using a photobacterial oxygen sensor for the study of microaerobiosis. J Appl Bacteriol 69, 539-549.

Kaysser, T. M., Ghaim, J. B., Georgiou, C. \& Gennis, R. B. (1995). Methionine- 393 is an axial ligand of the heme $b-558$ component of the cytochrome $b d$ ubiquinol oxidase from $E$. coli. Biochemistry 34, 13491-13501.

Kelly, M. J. S., Poole, R. K., Yates, M. G. \& Kennedy, C. (1990). Cloning and mutagenesis of the genes encoding the cytochrome $b d$ terminal oxidase complex in A. vinelandii: mutants deficient in the cytochrome $d$ complex are unable to fix nitrogen in air. $J$ Bacteriol 172, 6010-6019.

Kita, K., Konishi, K. \& Anraku, Y. (1984). Terminal oxidases of the Escherichia coli aerobic respiratory chain. II. Purification and properties of the cytochrome $b_{558}-d$ complex from cells grown with limited oxygen and evidence of branched electron-carrying systems. J Biol Chem 259, 3375-3381.

Kolonay, J. F., Moshiri, F., Gennis, R. B., Kaysser, T. M. \& Maier, R. J. (1994). Purification and characterisation of the cytochrome bd complex from Azotobacer vinelandii: comparison to the complex from Escherichia coli. J Bacteriol 176, 4177-4181.

Moshiri, F., Chawla, A. \& Maier, R. J. (1991a). Cloning, characterization, and expression in Escherichia coli of the genes encoding the cytochrome $d$ oxidase complex from Azotobacter vinelandii. J Bacteriol 173, 6230-6241.

Moshiri, F., Smith, E. G., Taormino, J. P. \& Maier, R. J. (1991b). Transcriptional regulation of cytochrome $d$ in nitrogen-fixing Azotobacter vinelandii. J Biol Chem 266, 32169-23174.

Paul, W. \& Merrick, M. (1989). The roles of the nifW, nifZ and nif $M$ genes of Klebsiella pneumoniae in nitrogenase biosynthesis. Eur J Biochem 178, 675-682.

Pearson, W. R. \& Lipman, D. J. (1988). Improved tools for biological sequence comparison. Proc Natl Acad Sci USA 85, 2444-2448.

Poole, R. K., Waring, A. J. \& Chance, B. (1979). The reactions of cytochrome $o$ with oxygen: low temperature and spectral studies. Biochem J 184, 369-389.

Poste, E., Kleiner, D. \& Oelze, J. (1983). Whole cell respiration and nitrogenase activities in Azotobacter vinelandii growing in an oxygen controlled continuous culture. Arch Microbiol 134, 68-72.

Postgate, J. R., Dixon, R., Hill, S. \& Kent, H. (1987). Nif genes in alien backgrounds. Philos Trans $R$ Soc Lond Biol Sci 317, 227-241.

Prentki, P. \& Kirsch, H. (1984). In vitro insertional mutagenesis with a selectable DNA fragment. Gene 29, 303-313.

Robson, R. L., Chesshyre, J. A., Wheeler, C., Jones, R., Woodley, P. R. \& Postgate, J. R. (1984). Genome size and complexity in Azotobacter chroococcum. J Gen Microbiol 130, 1603-1612. 
Rost, B., Casadio, R., Fariselli, P. \& Sander, C. (1995). Transmembrane helices predicted at $95 \%$ accuracy. Protein Sci 4, 521-533.

Sambrook, J., Fritsch, E. F. \& Maniatis, T. (1989). Molecular Cloning: a Laboratory Manual, 2nd edn. Cold Spring Harbor, NY: Cold Spring Harbor Laboratory.

Sawers, G. (1994). The hydrogenases and formate dehydrogenases of E. coli. Antonie Leeuwenhoek 66, 57-88.

Shah, V. K., Stacey, G. \& Brill, W. J. (1983). Electron transport to nitrogenase: purification and characterisation of pyruvate: flavodoxin oxidoreductase, the nifJ product. J Biol Chem 258, 12064-12068.

Smith, A., Hill, S. \& Anthony, C. (1990). The purification, characterization and role of the $d$-type cytochrome oxidase of Klebsiella pneumonaie during nitrogen fixation. J Gen Microbiol 136, 171-180.

Sprent, J. I. \& Sprent, P. (1990). Nitrogen Fixing Organisms. London \& New York: Chapman \& Hall.

Sturr, M. G., Krulwich, T. A. \& Hicks, D. B. (1996). Purification of a cytochrome $b d$ terminal oxidase encoded by the Escherichia col $i$ app locus from a $\Delta c y o \Delta c y d$ strain complemented by genes from Bacillus firmus OF8. J Bacteriol 176, 1742-1749.
Sun, J., Kahlow, M. A., Kaysser, T. M., Osbourne, J. P., Hill, J. J., Rohlfs, R. J., Hille, R., Gennis, R. B. \& Loehr, T. M. (1996). Resonance Raman spectroscopic identification of a histidine ligand of $b_{595}$ and the nature of the ligation of chlorin $d$ in the fully reduced Escherichia coli cytochrome bd oxidase. Biochemistry 35, 2403-2412.

Thorneley, R. N. F. \& Ashby, G. A. (1989). Oxidation of nitrogenase iron protein by dioxygen without inactivation could contribute to high respiratory rates of Aztobacter species and facilitate nitrogen fixation in other aerobic environments. Biochem J 261, 181-187.

Tseng, C.-P., Albrecht, J. \& Gunsallus, R. P. (1996). Effect of microaerophilic cell growth conditions on the expression of the aerobic (cyoABCDE and $c y d A B$ ) and anaerobic (narGHIJ, frd $A B C D$, and $d m s A B C)$ respiratory pathway genes in Escherichia coli. J Bacteriol 178, 1094-1098.

Young, J. P. W. (1992). Phylogenetic classification of nitrogenfixing organisms. In Biological Nitrogen Fixation, pp. 43-86. Edited by G. Stacey, R. H. Burris \& H. J. Evans. New York \& London: Chapman \& Hall.

Received 10 January 1997; revised 25 March 1997; accepted 1 April 1997. 